\title{
Vulnerability of Peasant Farmers to Climate Variability and Change in Semi-Arid Ethiopia
}

\author{
Muluken Andemo Gallo ${ }^{1^{*}} \quad$ Johnson O. Ayoade ${ }^{2} \quad$ Ibidun O. Adelekan ${ }^{2}$ \\ 1.Hawassa University Wondogent College of Forestry and Natural Resource, Ethiopia \\ 2.Faculty of the Social Sciences, Department of Geography, University of Ibadan, Ibadan, Nigeria
}

The research was financed by the African Union commission through the Pan African University, Institute of Life and Earth Science (including Health and Agriculture), University of Ibadan.

\section{Abstract}

Vulnerability study identifies the most vulnerable systems, regions, peoples, and the contributing factors to the vulnerability. Vulnerability study in climate change context is crucial to effectively and efficiently reduce the impacts of climate variability and change. This study assessed the vulnerability of peasant farmers to climate variability and change in semi-arid Ethiopia. The semi-arid zone was categorized into southern, central, and northern semi-arid. From each semi-arid zone, sample districts and sample peasant associations were selected respectively by manual lottery and purposive sampling techniques. 396 household surveys, 12 focus group discussions, and rainfall and temperature data were used for analysis. Principal Component Analysis (PCA) was used as the main analysis technique to construct the vulnerability indices. The central semi-arid zone with the vulnerability index of -3.07 was highly vulnerable at $\chi^{2}(2)=43.9986, \mathrm{P} \leq 0.05$, while the northern semi-arid zone with the vulnerability index of 4.83 was the least vulnerable. The lack of access to a clean drinking water source, main road, and market center were among the factors that contributed to farmers' vulnerability to climate variability and change in central semi-arid Ethiopia. The lack of access to information, small farmland holding size, and lack of multipurpose trees on the farmland are among the factors that have to be addressed in northern semi-arid even if it is relatively the least vulnerable. The level of farmers' vulnerability to climate variability and change and the contributing factors to farmers' vulnerability varies in semi-arid Ethiopia. Vulnerability reduction measures need to be specific to each semi-arid zone and priority needs to be given according to their degree of vulnerability.

Keywords: Peasant Farmers, Vulnerability, Climate Change, Semi-Arid Ethiopia

DOI: $10.7176 / \mathrm{JEES} / 10-5-07$

Publication date:May $31^{\text {st }} 2020$

\section{Introduction}

The degree of the impacts of climate change on a system or region depends on both the characteristics of the changes and the existing situation of a system or region (IPPC, 2001; Kelly and Adger, 1999; Yohe and Tol, 2002; Smit and Pilifosova, 2001. Thus, understanding the existing situation of a specific system or region in addition to the characteristics of the changes and events is very crucial to develop area or system specific intervention strategies to manage the impacts. To moderate the impacts of climate variability and change in already resourcelimited nations like Ethiopia, it is crucial to first identify who is more vulnerable, where they are exactly located, and the reason why they are vulnerable. Vulnerability study is among one of the commonly used approaches to identify areas, systems and peoples who needs immediate actions by considering both the existing situation of a specific system or region and the characteristics of changes in climatic variables. The Inter-governmental Panel on Climate Change (2001) definition of vulnerability: The degree to which a system is susceptible, or unable to cope with adverse effects of climate change, including climate variability and extremes, and vulnerability is a function of the character, magnitude and rate of climate variation to which a system is exposed, its sensitivity, and its adaptive capacity was adopted to conduct this study.

Adaptive capacity corresponds to the ability of the system to adjust to actual or expected climate changerelated stimuli or to cope with the consequences of the stimuli while sensitivity to the degree to which a system has the potential to be affected either negatively or positively by climate change stimuli, and exposure corresponds to the nature and degree to which a system is exposed to climate change.

Sensitivity and exposure together explain the potential impacts of climate change-related stimuli on a system while adaptive capacity describes the ability of the system to adapt and cope with the impacts of climate variability and change (Fellmann, 2012). A system is vulnerable when it is exposed and sensitive to climate change-related stimuli and at the same time has the limited ability to cope and adapt (Fellmann, 2012; Smit et al., 1999; Smit \& Wandel, 2006).

Vulnerability assessment can be done at country or regional level, community level even at household or individual level (Füssel \& Klein, 2006; Füssel, 2007) to compare communities, nations or regions, to assess future threat and to identify the factors that cause vulnerability so that vulnerability can be reduced (Adger et al., 2004). The biophysical and socio-economic vulnerability assessment approaches can be systematically combined together 
to describe vulnerability (Füssel, 2007). This approach is called integrated vulnerability assessment approach. According to Füssel (2007) \& Füssel \& Klein (2006), the biophysical approach corresponds to sensitivity in IPCC (2001) terminology and the socio-economic approach corresponds to adaptive capacity, while exposure has external dimension.

Indicators are the key elements in vulnerability assessment; they provide information on phenomenon's that are not immediately measurable (Vincent, 2004). To calculate the vulnerability by using indicator method, the weights or the contribution of each indicator to the vulnerability of a system can be assumed as equal (Cutter, Mitchell, and Scott, 2000) or different. There are several approaches to identify the weights or the contribution of each indicator to the vulnerability of a system instead of assigning equal weight. For instance, expert judgment (Kaly \& Pratt, 2000; Brooks, Adger, \& Kelly, 2005; Vincent, 2004; Torresan et al., 2012), principal component analysis (Cutter, Boruff, \& Shirley, 2003; Gbetibouo, Ringler, \& Hassan, 2010; Deressa, Hassan, \& Ringler, 2008; Filmer \& Pritchett, 2001), correlation with past disaster events (Brooks, Adger, \& Kelly, 2005), and use of fuzzy logic (Eakin \& Tapia, 2008). Each of these techniques has their own merits and demerits (Sharpe \& Andrew, 2012). Equal weighting and expert judgment techniques to assign weights to indicators were not used in this study. This is due to the fact that, all variables do not equally contribute to the vulnerability (Habb \& Mortsch, 2007) and smaller communities have limited expert knowledge respectively. Moreover, these two techniques are subjective techniques than a statistical model. Hence, a statistical model called Principal Component Analysis (PCA) was employed in this study to obtain the weights of each indicator.

The environmental and socioeconomic setting of the rural community is mainly governed by climatic variables in Ethiopia: a country whose economy is highly dependent on agriculture. This implies that areas having the same climatic conditions possess relatively the same environmental and livelihood activities. For instance, the environmental and livelihood activities in semi-arid regions are relatively similar and highly different from that of humid and hyper-arid. In Ethiopia, the environmental and socio-economic settings of the people within the administrative boundary are more heterogeneous than within relatively the same agro-ecological zones. This is due to the fact that the classification of the administrative boundaries at all level, i.e. ranging from the smallest administrative unit called Peasant Association (PA) to the state level is not based on the climatic variables. Thus, vulnerability studies based on agro-ecological zones can better facilitate adaptation and represents the level of vulnerability of a given region than studies based on the administrative boundary.

Ethiopia is a country with diverse agro-ecological zones. In these zones, the environmental condition and the socio-economic activities, such as the farming systems, social settings, technological and infrastructural developments are highly different apart from the difference in climatic variables. Variations in the aforementioned factors can contribute to the variation in the level of vulnerability across and even within the same climatic zones. Thus, the aim of this study was to measure the level of vulnerability of peasant farmers to climate variability and change in three semi-arid zones of Ethiopia (Southern, central and northern semi-arid zones) and to identify the major contributing factors to vulnerability.

\section{Methodology}

\subsection{Study area}

Hagere Mariam district is located in the southern Ethiopia on the paved Addis Ababa-Moyale highway at about $475 \mathrm{~km}$ from Addis Ababa, and lies between latitude $5^{0} 37^{\prime} \mathrm{N}$ and $5^{0} 39^{\circ} \mathrm{N}$ and between longitude $38^{\circ} 12^{`} \mathrm{E}$ and $38^{\circ} 15^{`} \mathrm{E}$ at an elevation 1885 meters above sea level. With an estimated area of 6,021.88 square kilometers, Hagere Mariam has a population density of 90.7 people per square kilometer (CSA, 2005). Maize, wheat, barley, haricot beans, sorghum, and teff are the major annual crops that are commonly grown in the area. In some parts, Ensete or the false banana is also grown, which offers a degree of security during famines. Coffee is also an important cash crop.

Ginir district is located to the south of Addis Ababa between latitude $7^{0} 07^{\prime} \mathrm{N}$ and $7^{0} 09^{\prime} \mathrm{N}$ and between longitude $40^{\circ} 41^{`} \mathrm{E}$ and $40^{\circ} 43^{`} \mathrm{E}$ at an elevation 1910 meters above sea level. With an estimated area of 2,350.63 square kilometers, Ginir has an estimated population density of 59.8 people per square kilometer (CSA, 2007). Maize, wheat, barley and beans are the major annual crops that are commonly grown in the area; Khat, and coffee are the two key cash crops in the area. Livestock rearing is also an integral part of the farming system.

Dehana district is located to the north of Addis Ababa between latitude $9^{0} 57^{\prime} \mathrm{N}$ and $9^{0} 58^{\prime} \mathrm{N}$ and between longitude $39^{\circ} 40^{\prime} \mathrm{E}$ and $39^{\circ} 41^{\prime} \mathrm{E}$ at an elevation 2502 meters above mean sea level. With an area of 1,643.07 square kilometers, the district has a population density of 66.78 persons per square kilometer (CSA, 2007). Teff, maize, sorghum and wheat are the major annual crops that are commonly grown in the area. Rearing a few number of livestock's such as goat, sheep and cattle is also part of the farming system in the area. The area is characterized as hot and dry, and the average annual temperature reaches up to 370c ("Dehana destination guide", n. d.). Degraded hills and valleys characterize the geomorphology of the area.

Kola Tembien district is located to the north of Addis Ababa between latitude $13^{0} 34^{\prime} \mathrm{N}$ and $13^{0} 39^{\prime} \mathrm{N}$ and between longitude $38^{\circ} 56^{\circ} \mathrm{E}$ and $39^{\circ} 03^{\circ} \mathrm{E}$ at an elevation 1810 meters above sea level. With an area of 2,538.39 
square kilometers, Kola Tembien has a population density of 52.92 persons per square kilometer (CSA, 2007). Cereals such as, teff, wheat and sorghum are the major crops that are commonly grown in the area. Livestock rearing is also part of the agricultural practice. Degraded hills and valleys mainly characterize the geomorphology of the area.

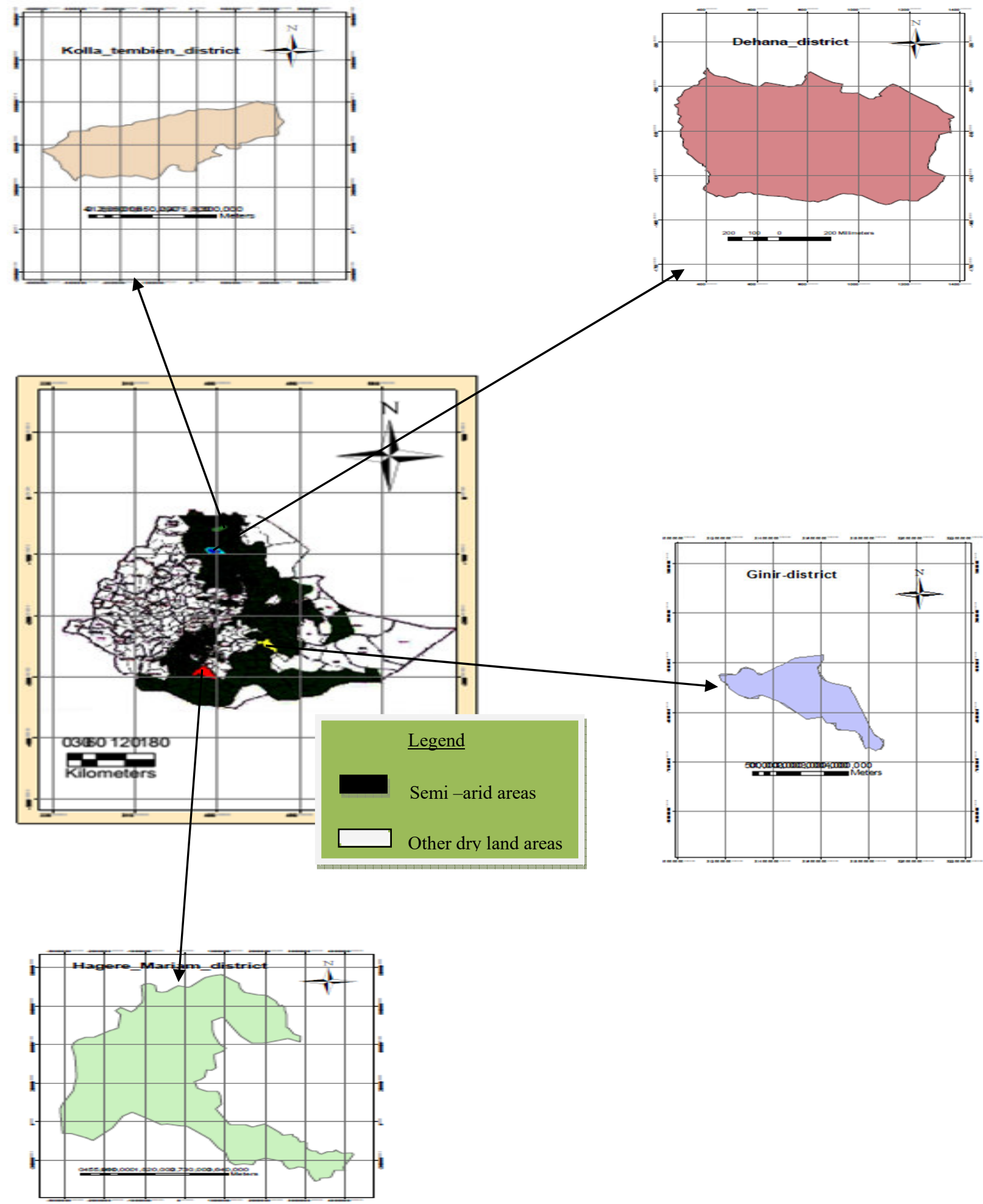

Figure 2.1. Study area

\subsection{Sampling and data collection}

Simple random sampling technique (manual lottery method) was used to select the sample districts from the three 
semi-arid zones of the country (southern, central and northern semi-arid zones). Hagere Mariam district from the southern semi-arid, Ginir district from the central semi-arid and Dehana and Kolla Tembien district from the northern semi-arid zone were selected. Two sample districts (Dehana and Kolla Tembien) from the northern semi -arid were selected due to its large area coverage. Three Peasant Associations (PAs) near the district center from each sample district were selected purposely to compare the three semi-arid zones based on their minimum vulnerability. Stratified random sampling technique based on wealth ranking was used to select the respondents from each peasant association proportionally from the different wealth classes (rich, medium and poor). This is due to the fact that, the way a rich household respond to climate change is different from that of medium or poor household. The number of respondents at each peasant association was determined based on their household population proportion. Including 10\% nonresponsive rate, a total of 421 semi-structured questionnaires were administered to collect data about the household and farm characteristics, income source technology source, infrastructure, cereal yield, and access to information and about other identified adaptive capacity and sensitivity indicators. However, only 396 questionnaires were used for analysis. Furthermore, one Focus Group Discussion (FGD) at each sample peasant association, making a total of 12 focus group discussions were conducted to address the issues that were not easily quantifiable in this study, such as the quality and adequacy of supply and service provision of infrastructure, institutions and other identified socio-economic indicators. Each focus group consist 6-10 members from the two gender classes. Rainfall and temperature data of the last 21 years (1995-2015) were gathered from the National Meteorological Agency (NMA), Combolicha, Mekele, Bale and Hawassa branch.

\subsection{Data analysis}

Descriptive statistics such as frequency, percentage and mean was used to summarize and describe the findings at each semi-arid zone. The vulnerability index of the three semi-arid zones was constructed by using the weight of the indicators determined by the Principal Component Analysis (PCA) technique together with the normalized value of the indicators. PCA was employed to reduce the original variables that were possibly correlated variables into orthogonal or uncorrelated lower number of principal components that most successfully capture the largest amount of information common to all the variables, and at the same time PCA was used to determine the weight or the contribution of each indicator to the vulnerability of peasant farmers to climate variability and change by using SPSS software version 16.0.

The dataset was first normalized or standardized by using centering and standard deviation normalization technique in order to adjust the values measured in different scales and units into comparable scale and unit and was checked for the suitability to run PCA by using the Kaiser-Meyer-Olkin (KMO) test for sampling adequacy and Bartlett's test of sphericity.

The weight and normalized value of the indicators were used in the following principal component model to construct the adaptive capacity index, sensitivity index and exposure index for each semi-arid zone (southern, central and northern).

$$
\left[Y=a_{i} x_{1}+\cdots+a_{i p} x_{p}, \text { for } i=1 \ldots p\right]
$$

Where, $Y=$ Adaptive capacity index or sensitivity or exposure index

$a=$ The weight or coefficient of the adaptive capacity or sensitivity or exposure indicator

$\mathrm{x}=$ The normalized value of the adaptive capacity or sensitivity or exposure indicator

For instance, the adaptive capacity index of each semi-arid zone was constructed by using the weight and the normalized value of the adaptive capacity indicators at each semi-arid zone in equation1. Similar procedure was followed to construct the sensitivity and exposure index.

Vulnerability was conceptualized in this study as the function of adaptive capacity, sensitivity and exposure, and vulnerability index was calculated as:

$V=A C_{i}-S_{i}+E_{i} \ldots \ldots \ldots \ldots \ldots \ldots \ldots . \ldots \ldots$

Where $\mathrm{V}=$ vulnerability index, $A C_{i}=$ Adaptive capacity index, $S_{i}=$ Sensitivity index, $E_{i}=$ Exposure index.

\section{Results and discussion}

\subsection{Adaptive capacity indicators}

Various adaptive capacity indicators were identified from the different aspects of the literature and were adapted to the Ethiopian context in order to measure the adaptive capacity of peasant farmers to climate variability and change.

\section{Wealth}

Wealth is among one of the key determinants of the nations, communities, and individuals adaptive capacity (IPCC, 2001; Smit \& pilifosova, 2001; Yohe \& Tol, 2002). The quality of the residential house and the size of farmland were taken as an indicator to measure the wealth status of the farmers.

\subsection{Quality of the residential house}

In Ethiopia, the residential house of the farming community was mainly two types. 1) Thatch roofing with wood/stone wall and mud floor. 2) Corrugated iron sheet roofing with wood/stone wall and mud floor. The two 
types of residential houses differ only by their roofing material. In Ethiopian context, a residential house with corrugated iron sheet roofing material belongs to the wealthier farmers and considered as a quality residential house in the community. Hence, in this study, the house roofing material was taken as the measure of the quality of the residential house, and the farmers with corrugated iron sheet roofing material residential house were considered as relatively wealthier. However, the measures of the quality of the residential house may vary from community to community and overtime.

\begin{tabular}{|l|c|c|c|}
\hline \multirow{2}{*}{ House roofing materials } & \multicolumn{3}{|c|}{ Semi-arid zones } \\
\cline { 2 - 4 } & Southern & Central & Northern \\
\hline Thatch & 44.6 & 53.6 & 72.1 \\
\hline Corrugated iron sheet & 55.4 & 46.4 & 27.9 \\
\hline
\end{tabular}

Source: Field Survey, 2015

As presented in table 1, 55.4\% of the respondents from the southern semi-arid zone, $46.4 \%$ of the respondents from the central semi-arid zone and $27.9 \%$ of the respondents from the northern semi-arid zone were with a residential house with corrugated iron sheet roofing material. This indicates that farmers in the southern semi-arid zone are relatively the wealthiest than the farmers in the central and northern semi-arid zone in terms of quality residential house.

\subsection{The size of farmland}

Farmers with the farmland size equal or greater than the average land holding size of the country, one hectare per household (EEC/EEPRI, 2002) were considered as wealthier. $87.1 \%$ of the respondents from the southern semiarid zone, $60.8 \%$ of the respondents from the central semi-arid zone and $37.1 \%$ of the respondents from the northern semi-arid zone were with the farmland $\geq 1$ ha. This indicates that the farmers in the southern semi-arid zone are relatively the wealthiest than the farmers in the central and northern semi-arid zone in terms of the size of farmland. Farmers with the larger arable land holding size may have a better productive soil as a result of the long fallow period which can help them to better adapt to climate variability and change.

\section{Dependency Ratio (DR)}

Total dependency ratio is the measure of the ratio of dependents, aged under 14 and above 65 to the working-age (labor force), aged from 15 to 64 (World Bank, 2015).

$$
\mathrm{DR}=\frac{\text { (Number of people aged } 0-14 \text { and those aged } 65 \text { and above) }}{\text { Number of people aged } 15-64} \times 100
$$

We found the greatest $(82 \%)$ dependency ratio per household in the southern semi-arid zone, followed by the central semi-arid zone (80\%) while the least $(63.5 \%)$ in the northern semi-arid zone. Higher dependency ratio reflects the higher burden on the economically active population/producers to support and provide the social services needed by children and older persons who are economically dependent i.e., the communities with the greater dependency ratio have the lesser adaptive capacity. Dependency ratio (DR) suggests that all children aged under 15 and persons aged above 65 as an economically dependent portion of the population. However, in many populations, people do not stop being economically active at age 65 , and it is not absolutely true that all persons aged 15-64 are economically active. Thus, the dependency ratio is the estimation not an absolute measure.

\section{Infrastructure}

The availability and access to key infrastructures determines the individuals and communities adaptive capacity to climate variability and change (IPCC, 2001; Smit \& Pilifosova, 2001; Kelly \& Adger, 1999). In this study, access to the main road and access to the drinking water source were taken as the key indicators of infrastructure to measure the adaptive capacity.

\subsection{Access to a drinking water source}

In Ethiopia, more than $80 \%$ of the country`s population lives in rural areas (WPP, 2015). To make those people have an access to drinking water, both international and local NGOs and the government was putting efforts by mainly focusing on building at least one common hand pump in each peasant association at or near to the peasant association center. Access to drinking water in this context refers to access to the hand pump water which has no measured water quality parameters. Hence, the term access to drinking water was used instead of access to clean drinking water, and the percentage of farmers with access to hand pump drinking water source was taken in this work as one of the measures of the ability of the community to adapt and cope with the effects of climate variability and change.

$76.7 \%$ of the respondents from the northern semi-arid zone, $64.4 \%$ of the respondents from the southern semiarid zone and $35 \%$ of respondents from the central semi-arid zone were with access to hand pump drinking water source. The percentage of farmers with access to drinking water source indicates the proportion of the population with access to an improved drinking water source in a dwelling or located within a convenient distance, in this case, 6 kilometer from the user's dwellings. The percentage of population with access to improved drinking water have been used as an indicator by many international institutions such as, WHO, UN,UNICEF, world bank and by many individual nations. However, this indicator has been critiqued for its lack of information on the adequacy and quality of service provision. To have an understanding of the quality and adequacy of water supply, focus 
group discussions were held at each sample PAs. The majority of the FGD members in all sample PAs noted that hand pumps were only visible at the PA centers and the issue of maintenance and the quality of the water was no longer the concern (no one was taking into account) once the pump built. Also, they have mentioned that People who were inhabited far from the PA centers usually collect their drinking water from the rivers and creeks, and they drunk without any pre-treatment. The statement offered by one of the participants from the central semi-arid, Ginir district, Ebisa PA summed up the comments of the majority of the participants concerning the issue of drinking water.

We used to collect drinking water from the creeks and rivers which were clean and not too far from our home. Now they are no longer available, we have lost our creeks and rivers. Our wives and children travel a long distance to collect water or they spend too long time waiting for their turn to collect water from the hand pump. The hand pump is for us who lives near to the PA center, but for our peoples who live far from the PA centers, finding clean drinking water is not an easy task. When we found the water we do not care about its quality, we just drink by saying the local proverb called "no ugly mother no bad water.

The finding indicates the need for all concerned stakeholders to work hard to make the farmers to have an access to improved drinking water source, and to work in improving the quality of the water for those who have already with access. A community without access to clean drinking water faces a relatively long list of social and economic challenges than a community which has access to it (UNDP, 2006). For instance, unhealthy labor force due to water-related health problems, wastage of productive time and energy by traveling a long distance to collect water, high medical expense, poor hygiene, low school attendance, especially adolescent girls etc.

\subsection{Access to the main road}

In Ethiopia, the majority of the population lives in rural areas and their livelihood is completely dependent on agriculture (FAO, 2015). Building networks of roadways can help to link those rural communities (the majority of the population) to the market and other service and facility centers. A road with a gravel surface type was the most common road throughout the country. Hence, in this study, the percentage of farmers with access to gravel road rather than asphalt road was taken as one of the relative measure of the ability of a community to adapt and cope with the effect of climate variability and change. $63.3 \%$ of the respondents from the southern semi-arid zone and $33.5 \%$ of the respondents from the northern semi-arid zone were with access to gravel surface road type while all of the respondents from the central semi-arid zone were with no access to the main road. The physical access to the gravel surface road could not tell us the current condition and challenges associated with it. The following FGD result summarized the condition and challenges associated with the main road. The gravel surface road was the common type of road throughout the country. However, all most all of the focus group members noted that the road networks with this surface type were not passable by all vehicle types and during the rainy season. The challenges associated with the road were summed up in the words of one participant from Dehana district as follows:

A car comes once in a week in a dry season, so that we need to register for our turn prior a week. Besides, many of us are not able to afford the transportation cost; as a result, we use animals and/or human as a means to transport agricultural goods to the market center or we just sell to the middleman by the lower price.

\section{Human capital}

The human capital of the community in this study was represented by the adult literacy rate. $80.2 \%$ of the respondents from southern semi-arid, $57.8 \%$ of the respondents from the northern semi-arid and $50.5 \%$ of the respondents from the central semi-arid were illiterates. Illiterates lack the ability to get, understand and interpret up-to-date information about the market chain, market price, consumer demands, product quality and standards, efficient way of production, weather and climate information etc., which are the key in production decision. Furthermore, illiterates may not readily adopt new agricultural technologies such as, drought resistant crop varieties, soil fertility amendment technologies, etc which are highly important in climate change adaption.

\section{Social capital}

Social capital refers to the social networks with shared norms and goals that enable the society to function or act collectively and effectively (Adger, 2003). It was measured by the percentage of farmers who participates in at least one government or community organization including, cooperatives. $64.6 \%$ of the respondents from the northern semi-arid zone, $57.7 \%$ of the respondents from the central semi-arid and $49.5 \%$ of the respondents from the southern semi-arid zone were participants at least in one government or community organization. In climate change and adaptation context, the better the ability of the society to act collectively against climate change impact, the higher the adaptive capacity (Adger, 2003; Wall \& Marzall, 2006).

\section{Engagement in alternative economic activities}

Alternative economic activities refer to the nonfarm income generation activities such as, employment, small-scale trade, petty- trade, gift and remittance and others, and the percentages of farmers engaged in at least one nonfarm 
activity were taken as one of the indicators of adaptive capacity. $4.1 \%$ of the respondents from the central semiarid, $8.9 \%$ of the respondents from the southern semi-arid and $9.85 \%$ of the respondents from the northern semiarid were engaged at least in one nonfarm activity. Farmers' engagements in profitable nonfarm activities can provide additional income and asset that can help them to better adapt and quickly recover from climate change related impacts (O'Brien et al., 2004; Byrne, 2014).

\section{Access to information}

It was measured by the percentage of farmers with a radio and/or television. $38.1 \%$ of the respondents from the central semi-arid zone, $40.6 \%$ of the respondents from the southern semi-arid and $31.3 \%$ of the respondents from the northern semi-arid zone were with a radio and/or television. Only ownership of radio and/or television could not tell us that farmers were really getting and understanding the production information including weather and climate information. As a result, during FGD farmers ' were assisted to share the production information that they got and understood from the radio and/or television.

The majority of the participants mentioned that they did not understand and/or use production information including weather and climate information from the radio and/or television. This implies the need to work hard on the ways how to disseminate and make information from the radio and/or television understandable by the farmers. Access to critical agricultural information's such as, about improved seeds and seedlings, market chain, demand and price, crop and livestock disease treatment and control, soil fertility amendment technologies and its application, new herbicides and pesticides and its application, weather and climate forecasts and early warning system etc., can determine the adaptive capacity, adoption of new technologies and adaptation choice of farmers to climate variability and change (Eakin \& Lemos 2006; O’Brien \& Vogel, 2003; Nhemachena \& Hassan, 2007; Baethgen et al., 2003).

\section{Access to agricultural technologies}

$45.5 \%$ of the respondents from the southern semi-arid zone, $59.7 \%$ of the respondents from the northern semi-arid zone and $47.4 \%$ of the respondents from the central semi-arid zone were with access to at least one "hard" agricultural technology source such as, improved seed and seedlings, new herbicides and pesticides and fertilizers. The quantitative result about the population with access with at least one agricultural technology does not reflect the timely availability, affordability, its impact on the production system and the challenges related to it. These issues were addressed during the FGD. Majority of the participants shared the idea that the price of the technologies was not easily affordable, technologies mainly reach to the farmers through development agents after passing through several government administrative stages, as a result, farmers get the technologies on their hand often times very late after their scheduled sowing date. Furthermore, they have mentioned that they lack knowledge and skills on how to apply or use the technologies, poor quality of the technologies especially, the seed and the lack of locally validated technologies, i.e., they are applying technologies that were developed outside their system. Access to a wide range of production technologies and the ability of the community to develop new technologies can determine the adaptive capacity and effective adaptation.

\section{Institutions}

Institutions are required to maintain the economy, health, the social and human capital of a country, and are the key to hold the society together, and thereby to enable adaptation (O'Riordan \& Jordan, 1999). In this work, the percentages of farmers with access to "soft" institutions, such as education, healthcare, veterinary, market, and microfinance were taken to measure the adaptive capacity of a community.

\subsection{Access to agricultural market center}

$25.9 \%$ of the respondents from the northern semi-arid zone, $7.9 \%$ of the respondents from the southern semi-arid zone and only $1 \%$ of the respondents from the central semi-arid zone were with access to district level market center. Only physical access to the market center cannot allow the farmers to enjoy the market price; the quality of produce and up-to-date produce price information are also the key. During the focus group discussion many of the participants were repeatedly mentioned the idea about, lack of transport, storage and packing facility, and lack of up-to-date produce price information. Because of these factors, farmers who have even physical access to the market centers were not really enjoying the market price. The idea which was shared by the many participants in all FGD sites was expressed by one of the FGD member from Hagere mariam district as follows.

I usually, sell my agricultural goods to the middleman by the price determined by the middleman, because I am unable either to transport to the market center or to get and understand up-to-date product price information in order to reduce the unfair price burden imposed by the middleman.

Access to agricultural market centers can enhance agricultural production and productivity, boost income and economic growth, reduce poverty and hunger etc. (Magesa et al., 2014; Mano et al., 2003; Lothoré \& Delmas, 2009).

\subsection{Access to microfinance services}

Microfinance service involves the supply of the basic financial services to smallholder farmers (Visconti, 2015; Agrawala \& Carraro, 2010; Hammill, Matthew, \& Mccarter, 2008). 80.2\% of the respondents from the southern 
semi-arid, $34 \%$ of the respondents from the central semi-arid and $40.9 \%$ of the respondents from the northern semi-arid zone were the users of microfinance institutions. Providing microfinance services to small-scale farmers enable farmers to build assets, increase incomes and reduce their vulnerability to economic stress and external shocks including, climate change (Dhakal, 2010; Agrawala \& Carraro, 2010; Hammill et al., 2008).

\subsection{Access to veterinary service}

$64.9 \%$ of the respondents from the central semi-arid, $44.35 \%$ of the respondents from the northern semi-arid were with access to veterinary service, while respondents from the southern semi-arid zone were with no access to veterinary service. Climate change affects livestock production mainly by impairing the pasture and water availability and quality, and by facilitating the spread of livestock diseases (Hopkins \& Del Prado, 2007; Thornton, et al., 2009). Thus, the farmers with access to veterinary center can have a healthy livestock and better production, so that they can easily cope and adapt to the effects of climate change than the farmers with no access to it.

\subsection{Access to education}

Access to education is among the key determinants of adaptive capacity (Yohe \& Tol, 2001; IPCC, 2001), and was measured in this study by the percentage of the population with access to primary and secondary school.

$64.9 \%$ of the respondents from the central semi-arid zone, $83.45 \%$ of the respondents from the northern semiarid and $72.3 \%$ of the respondents from the southern semi-arid were with access to primary school, while $23.4 \%$ of the respondents from the northern semi-arid, $9.9 \%$ of the respondents from the southern semi-arid and $2.06 \%$ of the respondents from the central semi-arid zone were with access to secondary school.

Education is the key instrument to pull families and communities out of the poverty cycle (Melin, 2001). In climate change context, by breaking illiteracy, education can make farmers able to get, understand and interpret production information such as, market and climate information, help farmers to make right production decision, enable farmers to become an experts on their farm, assist farmers to adopt and apply improved production technologies, develop farmers creativity in developing strategies to cope and adapt to the effects of climate change, make farmers to lead healthy and planned life etc. Moreover, providing access to education keep the countries away from putting surplus unproductive labor back to subsistence and climate sensitive agriculture.

During FGD, regarding education, almost all of the FGD members appreciated the efforts made so far by the government to make the primary school accessible by their children. However, they have pointed out that, they lack capital to send their students to secondary school which was somehow far from their settings.

\subsection{Access to health care service}

In climate change and adaptive capacity context, access to improved health care services can enhance the adaptive capacity to climate change by maintaining healthier community and by reducing the burden from increasing climate-related disease such as, malaria, heat-related diseases, respiratory disease etc. (Campbell-Lendrum \& Woodruff, 2006; WHO, 2003; IPCC, 2001). 64.95\% of the respondents from the central semi-arid zone, $77.2 \%$ of the respondents from the southern semi-arid zone and $78 \%$ of the respondents from the northern semi-arid zone were with access to health post, while $2.06 \%$ of the respondents from the central semi-arid zone, $9.9 \%$ of the respondents from the southern semi-arid zone and $22.05 \%$ of the respondents from the northern semi-arid were with access to hospital or health center. Having access to health care services can provide: the overall physical, social and mental health status, prevention of disease and disability, detection and treatment of health conditions, quality of life, reduce life expectancy, reduce child marriage, reduce maternal deaths, combat HIV etc. (WHO, 2003). During the FGD, regarding the quality and adequacy of the health care service, the majority of the focus group discussion members have mentioned about the unavailability of experts, facilities and drugs, high health service bill and the poor transportation system to bring patients to the place where better health facilities were located.

\subsection{Sensitivity indicators \\ 1. Cereal yield}

Climate variability and change including extreme events are greatly reducing the cereal yield more in small-scale agriculture and will continue to do so. Thus, in this study, it was assumed that, the farmers with the lesser cereal yield per hectare per year, the more sensitive to the effects of climate stimuli than the farmers with the higher cereal yield per year per hectare. Hence, the average cereal yield $(\mathrm{kg})$ per household per hectare per year was taken in this work as one of the measures of the degree of sensitivity of a community to climate variability and change. High cereal yield help farmers to store surplus grain as a reserve for emergency time (FAO, 2011). The result of this study shows that the farmers in the central semi-arid zone produce relatively the highest cereal yield $(202.9 \mathrm{~kg})$ per household per hectare per year, while the farmers in the southern semi-arid produce the least $(131 \mathrm{~kg})$.

\section{Livestock number}

Livestock's are sensitive or has the potential to be affected by the climate change through its effect on livestock production mainly by impairing pasture and water availability and quality, and by facilitating the spread of livestock diseases (Hopkins \& Del Prado, 2007; Thornton, et al., 2009). As a result, in this study, it was assumed that, the farmers with the greater number of livestock, the more sensitive than the farmers with the fewer numbers 
of livestock. On the other hand, it is obvious that food crops that are grown on already poor soil under limited/no irrigation, like in Ethiopia, are more sensitive to climate variability and change than the livestock. For instance, during the drought period, animals can get their feed from drought resistant shrubs, trees and from already stored fodder for dry season, and can be driven to big natural water source for watering. Furthermore, animals have the natural ability to withstand high heat stress and flood effect than the common food crops. So that, livestock can serves as an important buffer for farmers in times of crop failure (Fafchamps et al., 1996). We found the respondents from the southern semi-arid zone owned the greatest average number of livestock per household (13.3) followed by the central semi-arid (9), while the respondents from the northern semi-arid zone owned the least number of livestock per household (6.8).

\section{Irrigation and water harvesting}

The water and its whole cycle are highly sensitive or have the potential to be affected by the global warming. Nowadays, due to global warming, the timing of the rain has been changing, and agricultural drought is prevailing; which is pushing rainfed agriculture dependent farmer into destitute. Thus, it was assumed in this study that, the farmers who were the beneficiaries from the community irrigation scheme or with their own water harvesting technologies, the less sensitive than the farmers who were not the beneficiaries from the community irrigation scheme or without his/her own water harvesting technologies. $0.12 \%$ and $0.13 \%$ of the respondents from the southern and northern semi-arid respectively were the beneficiaries of irrigation and water harvesting scheme, while none of the respondents were the beneficiaries from the central semi-arid zone. Supplementing or replacing rainfed agriculture with irrigation has become one of the widely assumed effective measures of climate change adaption (IPCC, 2007). Improved irrigation reduces crop failure as a result of drought and enables farmers to grow food crops in a dry season.

\section{The soil}

Some of the physical, biological and chemical properties of the soil are very sensitive to climate change or have the potential to be affected by the climate change; which in turn affects the productivity of the soil. The degree of soil sensitivity can be measured and compared by considering its several physical, biological and chemical properties. However, it has been measured and compared by the amount of fertilizer applied per hectare per growing season. Unfortunately, there was no convincing information regarding fertilizer application in the study area. Thus, the presence of multipurpose trees on the farmland was taken to measure the sensitivity of the soil, by assuming that the farmlands without trees are the more sensitive. $94 \%$ of the respondents from the southern semiarid zone, $81 \%$ of the respondents from the central semi-arid zone and $16.7 \%$ of the respondents from the northern semi-arid zone had multi-purpose trees on their farmland. Trees on the farmer's farmland supply a wide range of benefits to the farm households, including food, medicine, livestock feed, timber, shade, nitrogen-fixing trees, as a substitute or complements for chemical fertilizer, erosion barrier, micro-climate amelioration, etc.

\subsection{Exposure}

Exposure was measured by the frequency of extreme events (drought and flood), long-term mean of surface air temperature and rainfall and by the variability of surface air temperature and rainfall measured by the coefficient of variation $(\mathrm{CV})$.

Table 3.2. Summary of the findings on the measures of exposure

\begin{tabular}{|l|c|c|c|}
\hline & Central semi-arid & Southern semi-arid & Northern semi-arid \\
\hline Total annual rainfall $(\mathrm{mm})$ & 133.98 & 802.53 & 288.81 \\
\hline Annual rainfall variability $(\mathrm{CV})$ & 38.71 & 22.14 & 20.93 \\
\hline Mean annual temperature $\left({ }^{0} \mathrm{c}\right)$ & 20.06 & 18.32 & 20.65 \\
\hline Annual temperature variability $(\mathrm{CV})$ & 15.9 & 4.89 & 4.75 \\
\hline Frequency of flood & 0 & 0 & 0 \\
\hline Frequency of drought & 4 & 9 & 8 \\
\hline
\end{tabular}

\section{Vulnerability indices}

To construct the vulnerability indices, the dataset were normalized and checked for the suitability to run PCA by using the Kaiser-Meyer-Olkin (KMO) test for sampling adequacy and Bartlett's test of sphericity. Then weights were attached to each variables/indicators by employing Principal Component Analysis (PCA).

Table 3.3. KMO and Bartlett's Test Result

\begin{tabular}{|l|l|l|}
\hline Kaiser-Meyer-Olkin Measure of Sampling Adequacy. & .772 \\
\hline \multirow{3}{*}{ Bartlett's Test of Sphericity } & Approx. Chi-Square & 2322.696 \\
\cline { 2 - 3 } & df & 190 \\
\cline { 2 - 3 } & Sig. & .000 \\
\hline
\end{tabular}

Both the Bartlett's test of sphericity and the Kaiser-Meyer-Olkin (KMO) measure of sampling adequacy revealed the suitability of the dataset to run the PCA. Both the Eigenvalue rule or the Kaiser criterion and the scree 
plot techniques were used to determine the number of principal components that should be retained to explain the maximum variance. Accordingly, the first three components, which have explained $63.667 \%$ of the total variance in the dataset were retained for further analysis. Usually, the principal components are explained by the variables that have high component loadings after rotation. Verimax rotation was used to determine exactly which variable loads the most to which component.

Loadings are the correlation between variables and the principal component, and they are equivalent to the standardized regression coefficient in multiple linear regression (when variables are standardized, i.e., converted to Z-score) and are called $\beta$-weights (Beaumont, 2012). Beta weights represent the contribution of the variables to the multiple linear regression equation or to the component score while holding other variables constant (Johnson, 2012). Hence, the loadings are equivalent to the weights of the variables (OECD, 2008). Hence, in this study, loadings after rotation and weights have the same meaning and were used as a standardized coefficient in principal component analysis model to estimate the composite index. However, only the weights of the variables that loaded to the first three components (the retained components) were used to construct the indices.

Table 3.4. Weight of the indicators

\begin{tabular}{|l|r|}
\hline Indicators & weight \\
\hline Rainfall Variability & -0.947 \\
\hline Mean annual temperature & 0.947 \\
\hline Temperature variability & 0.947 \\
\hline Access to the main road & -0.947 \\
\hline Mean annual rainfall & -0.947 \\
\hline Trees on farmland & 0.720 \\
\hline Access to health post & 0.934 \\
\hline Access to primary school & 0.929 \\
\hline Access to veterinary service & 0.903 \\
\hline Access to agricultural technology & 0.680 \\
\hline Access to health center/hospital & 0.949 \\
\hline Access to market & 0.949 \\
\hline Access to secondary school & 0.946 \\
\hline
\end{tabular}

The weights and normalized values of the indicators were used in the following model to construct the vulnerability indices.

$$
\begin{gathered}
{\left[Y=a_{i} x_{1}+\cdots+a_{i p} x_{p}, \text { for } i=1 \ldots p\right] \ldots \ldots . .3} \\
\text { Where, } \mathrm{a}=\text { the weight/coefficient of the indicator } \\
\mathrm{x}=\text { the normalized value of the indicator } \\
\mathrm{Y}=\text { vulnerability index }
\end{gathered}
$$

Vulnerability index $(\mathrm{V})=$ Adaptive capacity index (ACI) - (sensitivity index + exposure index). The vulnerability index of southern semi-arid was calculated as follows.

$\mathrm{V}=[(0.934 * 0.523)+(0.929 *-0.203)+(0.903 *-1.094)+(0.680 *-0.764)+(0.949 *-0.140)+$ $(0.949 *-0.288)+(0.946 *-0.172)]-[(-0.947 * 1.153)+(-0.947) *(1.126)]=\mathbf{0 . 3 8}$

The same procedure was followed to calculate the vulnerability indices for the central and northern semi-arid. Table 3.5. Adaptive capacity index, sensitivity and exposure index and vulnerability index

\begin{tabular}{|l|c|c|c|}
\hline & Adaptive capacity index & Sensitivity + Exposure index & Vulnerability index \\
\hline Southern semi-arid & -1.776 & -2.158 & 0.38 \\
\hline Central semi-arid & -1.724 & 1.341 & -3.07 \\
\hline Northern semi-arid & 5.65 & 0.817 & 4.83 \\
\hline
\end{tabular}

The null hypothesis: There is no statistically significant difference in the level of vulnerability of peasant farmers in three semi-arid zones of Ethiopia was tested by using the chi square test.

Table 3.6. Chi-square test

\begin{tabular}{|l|c|c|c|c|}
\hline & $\begin{array}{l}\text { Observed } \\
\text { (Oi) }\end{array}$ & $\begin{array}{l}\text { Expected } \\
(\text { Ei })\end{array}$ & Oi -Ei & $(\text { Oi - Ei })^{2}$ \\
\hline Southern & 0.38 & 0.713 & -0.333 & 0.111 \\
\hline Central & -3.07 & 0.713 & -3.783 & 14.311 \\
\hline Northern & 4.83 & 0.713 & 4.117 & 16.949 \\
\hline Sum & 2.14 & & & 31.371 \\
\hline
\end{tabular}

The null hypothesis was rejected at $\chi^{2}(2)=43.9986, \mathrm{P} \leq 0.05$, and concluded that the difference in the level of vulnerability of peasant farmers in three semi-arid zones of Ethiopia was not by chance.

The central semi-arid zone with the vulnerability index of -3.07 was highly vulnerable at $\chi^{2}(2)=43.9986, P \leq$ 0.05 , while the northern semi-arid zone with the vulnerability index of 4.83 was the least vulnerable. Factors such as lack of access to clean drinking water source, main road, market center, education (both to primary and 
secondary school) and health care services, the lack of engagement in nonfarm economic activities and use of microfinance, the relatively highest temperature and rainfall variability and lowest annual rainfall contributed to the greatest vulnerability of the central semi-arid zone. Lack of access to information, small farmland holding size, lack of multipurpose trees on the farmland and lack of quality residential house are the factors that have to be addressed in northern semi-arid even if it is relatively less vulnerable. In the southern semi-arid, the lack of access to agricultural technologies, veterinary service, and highest illiteracy rate, lack of collective action and lower cereal yield were the factors that mainly contributed to its vulnerability.

\section{Conclusion}

Conducting integrated vulnerability assessment in a climate change context is vital to identify the most vulnerable systems, regions, peoples, and the contributing factors to the vulnerability. Hence, vulnerability assessment helps resource-limited nations, like Ethiopia to effectively and efficiently reduce the impacts of climate change and extreme events. Since the level of farmers' vulnerability to climate variability and change and the contributing factors to farmers' vulnerability varies in semi-arid Ethiopia, vulnerability reduction measures need to be specific to each semi-arid zone and priority needs to be given according to their degree of vulnerability.

\section{References}

Adger, W. N., Brooks, N., Bentham, G., \& Agnew, M. (2004). New indicators of vulnerability and adaptive capacity. Tyndall Centre for Climate Research, Technical report 7, January, 2004

Adger, W. N. (2003). Social Capital, Collective Action, and Adaptation to Climate Change.

Agrawala, S., \& Carraro, M. (2010). Assessing the Role of Microfinance in Fostering Adaptation to Climate Change, 82.2010

Baethgen, W. E., Meinke,H., \& Gimene, A. (2003). Adaptation of agricultural production systems to climate variability and climate change: Lessons learned and proposed research approach. Paper presented at climate adaptation. net conference "Insights and tools for adaptation: learning from climate variability", 18-20 November, 2003, Washington, DC.

Beaumont, R. (2012). An introduction to Principal Component Analysis \& Factor Analysis Using SPSS 19 and R (psych package ), (April)

Brooks, N., Adger, W. N., \& Kelly, P. M. (2005). The determinants of vulnerability and adaptive capacity at the national level and the implications for adaptation, 15, 151-163. http://doi.org/10.1016/j.gloenvcha.2004.12.006

Byrne, T. R. (2014). Household adaptive capacity and current vulnerability to future climate change in rural Nicaragua.

Campbell-lendrum, A. D., Woodruff, R., Campbell-lendrum, D., \& Woodruff, R. (2006). Comparative Risk Assessment of the Burden of Disease from Climate Change, 114(12), 1935-1941. http://doi.org/10.1289/ehp.8432

CSA. (2007). National census, Central Statistical Agency of Ethiopia, 2007

CSA. (2005). National census, Central Statistical Agency of Ethiopia, 2005

Cutter, S. L., Boruff, B. J., \& Shirley, W. L. (2003). Social vulnerability to environmental hazards. Social science quarterly, 84(2), 242-261.

Cutter, S. L., Mitchell, J. T., Scott, M. S.,. (2000). Revealing the Vulnerability of People and Places : A Case Study of Georgetown, 90(4), 713-737.

Dehana Destination guide: Delve in to Dehana in Ethiopia (n.d.). Trip suggest Web site, Retrieved September 17, 2015, from http://trip-suggest.com/ethiopia/amhara-region/dahana/

Deressa, T., Hassan, R. M., \& Ringler, C. (2008). Measuring Ethiopian Farmers ' Vulnerability to Climate Change Across Regional States. Food Policy, 806(October), 32. http://www.ifpri.org/publication/measuringethiopian-farmers-vulnerability-climate-change-across-regional-states

Dhakal, N. H. (2010). Emerging good practices among leading nepalese microfinance institutions, (october).

Eakin, H., \& Tapia,B. (2008). Insights into the composition of household vulnerability from multicriteria decision analysis. Global Environmental Change 18(1): 112-127

Eakin, H., \& Lemos,M.C. (2006). Adaptation and the State : Latin America and the challenge of capacity-building under globalization, (November). http://doi.org/10.1016/j.gloenvcha.2005.10.004

EEC/EEPRI. (2002). Land Tenure and Agricultural Development in Ethiopia., Addis Ababa: EEC/EEPRI.

Fafchamps, M., Udry, C., \& Czukas, K. (1996). Drought and Saving in West Africa : Are Livestock a Buffer Stock ? 1, (December 1994).

FAO. (2015). FAO' s work on climate change. United Nations climate change conference, 2015

FAO. (2011). Building Networks for Market Access: Lessons Learned from the Rural Knowledge Network (RKN) Pilot Project for East Africa (Uganda, Kenya and Tanzania). FAO/Government Cooperative Programme, Research and Extension Branch Office of Knowledge Exchange, Research and Extension, Rome, 2011 
Fellmann, T. (2012). The assessment of climate change-related vulnerability in the agricultural sector : reviewing conceptual frameworks. Building Resilience for Adaptation to Climate Change in the Agricultural Sector, (i), $37-62$.

Filmer, D., \& Pritchett, L. H. (2001). Estimating Wealth Effects without Expenditure Data-or Tears : An Application to Educational Enrollments in States of India, 38(1), 115-132. http://www.jstor.org/stable/3088292

Füssel, H. M. (2007). Vulnerability: A generally applicable conceptual framework for climate change research. Global Environmental Change, 17(2), 155-167.

Füssel, H. M., \& Klein, R. J. (2006). Climate change vulnerability assessments: An evolution of conceptual thinking. Climatic Change, 75(3), 301-329.

Gbetibouo, G. A., Ringler, C., \& Hassan, R. (2010). Vulnerability of the South African farming sector to climate change and variability: An indicator approach, 34, 175-187.

Grain storage techniques - Evolution and trends in developing countries: Who stores and why? (n. d.). FAO Web site, Retrieved November 02, 2016, from http://www.fao.org/docrep/t1838e/T1838E04.HTM

Habb, A., \& Mortsch, L. ( 2007). Floods: Mapping Vulnerability in the Upper Thames Watershed under a Changing Climate.

Hammill, A., Matthew, R., \& Mccarter, E. (2008). Microfinance and Climate Change Adaptation, 39(4), $113-122$.

Hopkins, A., \& Del Prado, A. (2007). Implications of climate change for grassland in Europe: Impacts , adaptations and mitigation options : A review, (December). http://doi.org/10.1111/j.1365-2494.2007.00575.

IPCC. (2007). Climate Change 2007: Synthesis Report .Contribution of Working Group I, II and III to the forth Assessment Report of the Intergovernmental Panel on Climate Change. IPCC, Geneva, Switzerland

IPCC. (2001). Climate change 2001: Impacts, Adaptation, and Vulnerability. Intergovernmental panel on climate change. Cambridge, UK: Cambridge University Press

Johnson, J. W. (2012). History and Use of Relative Importance Indices in Organizational Research, 7(3), 238-257. http://doi.org/10.1177/1094428104266510

Kaly, U., \& Pratt, C. (2000). EVI Phase II Report Environmental Vulnerability Index : Development and provisional indices and profiles for Fiji, Samoa, Tuvalu and Vanuatu.

Kelly, P. M., \& Adger, W. N. (1999). Assessing vulnerability to climate change and facilitating adaptation. Centre for Social and Economic Research on the Global Environment.

Lothoré, A., \& Delmas, P. (2009. Market Access and Agricultural Product Marketing: Promoting farmers' initiatives

Magesa, M. M., Michael, K., \& Ko, J. (2014). Access to Agricultural Market Information by Rural Farmers in Tanzania, 4(7), 7-9.

Mano, R., Isaacson, B., \& Dardel, P. (2003). Identifying Policy Determinants of Food Security Response and Recovery in the SADC Region: The Case of the 2002 Food Emergency by, (March), 26-27.

Melin, E. M. (2001). - a Way out of Poverty, (12).

Nhemachena, C., \& Hassan, R. (2007). Micro-Level Analysis of Farmers' Adaptation to Climate Change in Southern Africa.

O`Brien, K. O., Leichenko, R., Kelkar, U., Venema, H., Aandahl, G., Tompkins, H., ... West, J. (2004). Mapping vulnerability to multiple stressors: climate change and globalization in India, 14, 303-313. http://doi.org/10.1016/j.gloenvcha.2004.01.001

O'Brien, K., \& Vogel, C. (2003). Coping with climate variability: the use of seasonal climate forecasts in Southern Africa. Ashgate Publishing Ltd.

OECD.(2008.). Handbook on Constructing Composite Indicators: Methodology and user guide.

O`Riordan, T., \& Jordan, A. (1999). Institutions, Climate change and Cultural Theory: Towards a Common Analytical Framework. Center for Social and Economic Research on the Global Environment, University College, London and University of East Angelia, Norwich, UK9(1999) 81-93

Sharpe, A., \& Andrews, B. (2012). An assessment of weighting methodologies for composite indicators: the case of the index of economic well-being.

Smit, B. \& Wandel, J. 2006. Adaptation, adaptive capacity and vulnerablity. Global Environmental Change, 16 : 228-292.

Smit, B., \& Pilifosova, O. (2001). Adaptation to Climate Change in the Context of Sustainable Development and Equity

Smit, B., Burton, I., Klein, R.J.T. \& Street, R. 1999. The science of adaptation: A framework for assessment. Mitigation and Adaptation Strategies for Global Change, 4: 199-213.

Thornton, P. K., Maria, A., Notenbaert, O., \& Herrero, M. (2009). The Impacts of Climate Change on Livestock and Livestock Systems in Developing Countries: A Review of What We Know ..., (March 2015). http://doi.org/10.1016/j.agsy.2009.05.002

Torresan, S., Critto, A., Rizzi, J., Marcomini, A., \& Division, C. (2012). Assessment of coastal vulnerability to 
climate change hazards at the regional scale: the case study of the North Adriatic Sea, 2347-2368. http://doi.org/10.5194/nhess-12-2347-2012

UNDP. (2006). Beyond scarcity: Power, poverty and the global water crisis. Human Development Report 2006.

United Nation division`s world population prospects. (2015). Monitoring global population trend, the 2015 revision, New York, 2015.

Vincent, K. (2004). Creating an index of social vulnerability to climate change for Africa. Change, 56(August), 41. Retrieved from http://www.tyndall.ac.uk/publications/working_papers/wp56.pdf

Visconti, R. M. (2015). A survey on microfinance for developing countries :, 1(September).

Wall, E., \& Marzall, K. (2006). Adaptive Capacity for Climate Change in Canadian Rural Communities, 11(4), $373-397$.

WHO. (2003). Climate change and human health: Risks and responses. Geneva, 2003

World Bank. (2015). Population total, the 2015 revision. Retrieved May 12, 2016, from http://data.worldbank.org/indicator/SP.POP.TOTL

Yohe, G., \& Tol, R. S. J. (2001). Indicators for Social and Economic Coping Capacity- Moving Toward a Working Definition of Adaptive Capacity, (July 2001), 24-40. http://doi.org/10.1016/S0959-3780(01)00026-7

Yohe, G., \& Tol, R. S. J. (2002). Indicators for social and economic coping capacity: Moving toward a working definition of adaptive capacity, $12,25-40$

\section{Appendices}

Appendix 1. Total Variance Explained

\begin{tabular}{|c|c|c|c|c|c|c|c|c|c|}
\hline \multirow[b]{2}{*}{ Component } & \multicolumn{3}{|c|}{ Initial Eigen values } & \multicolumn{3}{|c|}{$\begin{array}{l}\text { Extraction Sums of Squared } \\
\text { Loadings }\end{array}$} & \multicolumn{3}{|c|}{$\begin{array}{l}\text { Rotation Sums of Squared } \\
\text { Loadings }\end{array}$} \\
\hline & Total & $\%$ Variance & Cumulative $\%$ & Total & $\%$ Variance & Cumulative \% & Total & $\%$ Variance & Cumulative $\%$ \\
\hline 1 & 7.990 & 42.055 & 42.055 & 7.990 & 42.055 & 42.055 & 5.696 & 29.977 & 29.977 \\
\hline 2 & 2.749 & 14.470 & 56.525 & 2.749 & 14.470 & 56.525 & 3.352 & 17.641 & 47.617 \\
\hline 3 & 1.672 & 8.799 & 65.324 & 1.672 & 8.799 & 65.324 & 3.049 & 16.050 & 63.667 \\
\hline 4 & 1.333 & 7.016 & 72.340 & 1.333 & 7.016 & 72.340 & 1.492 & 7.853 & 71.520 \\
\hline 5 & 1.219 & 6.415 & 78.755 & 1.219 & 6.415 & 78.755 & 1.375 & 7.235 & 78.755 \\
\hline 6 & 0.942 & 4.960 & 83.715 & & & & & & \\
\hline 7 & 0.850 & 4.473 & 88.188 & & & & & & \\
\hline 8 & 0.776 & 4.086 & 92.274 & & & & & & \\
\hline 9 & 0.538 & 2.834 & 95.108 & & & & & & \\
\hline 10 & 0.361 & 1.900 & 97.007 & & & & & & \\
\hline 11 & 0.298 & 1.569 & 98.576 & & & & & & \\
\hline 12 & 0.111 & .585 & 99.162 & & & & & & \\
\hline 13 & 0.108 & .566 & 99.728 & & & & & & \\
\hline 14 & 0.033 & .172 & 99.900 & & & & & & \\
\hline 15 & 0.019 & .100 & 100.000 & & & & & & \\
\hline 16 & 0.000 & 0.000 & 100.000 & & & & & & \\
\hline 17 & 0.000 & 0.000 & 100.000 & & & & & & \\
\hline 18 & 0.000 & 0.000 & 100.00 & & & & & & \\
\hline 19 & 0.000 & 0.000 & 100.000 & & & & & & \\
\hline
\end{tabular}

Extraction Method: Principal Component Analysis. 
Appendix 2. The scree plot

\section{Scree Plot}

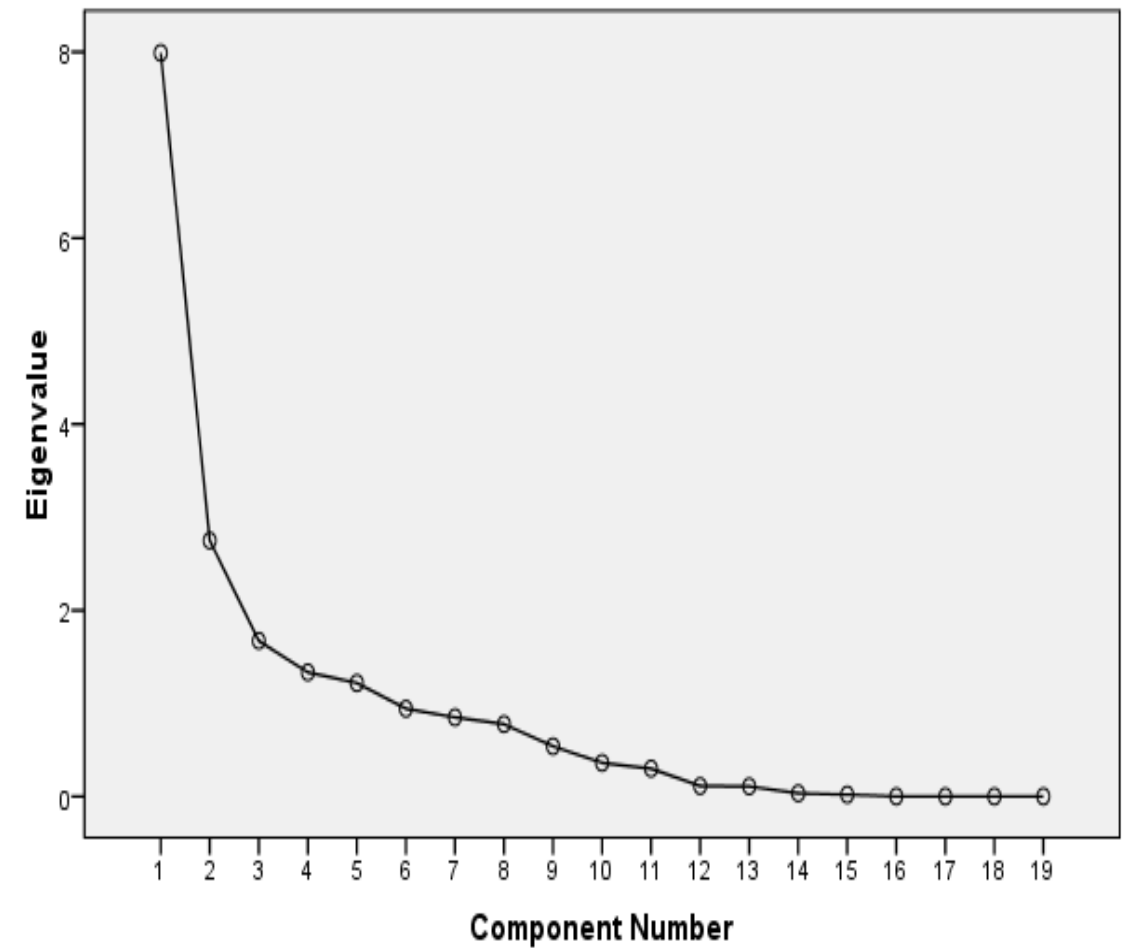

Appendix 3: Rotated Component Matrix

\begin{tabular}{|c|c|c|c|c|c|}
\hline & \multicolumn{2}{|c|}{ components } & & & \\
\hline & 1 & 2 & 3 & 4 & 5 \\
\hline Rainfall variability & -.947 & & & & \\
\hline Temperature variability & .947 & & & & \\
\hline Mean annual Temperature & .947 & & & & \\
\hline Access to the main road & -.947 & & & & \\
\hline Mean annual rainfall & -.947 & & & & \\
\hline Trees on farmland & .702 & & & & \\
\hline Access to primary school & & .929 & & & \\
\hline Access to health post & & .934 & & & \\
\hline Access to veterinary service & & .903 & & & \\
\hline Access to technology source & & .680 & & & \\
\hline Access to the hospital or health center & & & .949 & & \\
\hline Access to market center & & & .949 & & \\
\hline Access to secondary school & & & .946 & & \\
\hline Quality residential house & & & & -0.79 & \\
\hline Literacy rate & & & & -.612 & \\
\hline Size of farmland & & & & .659 & .382 \\
\hline Average livestock per $\mathrm{HH}$ & & & & .615 & 0.38 \\
\hline Average cereal yield & & & & & .677 \\
\hline Dependency ratio & & & & & .419 \\
\hline
\end{tabular}

Extraction Method: Principal Component Analysis

Rotation Method: Varimax with Kaiser Normalization 
Appendix 4: Normalized values of indicators

\begin{tabular}{|c|c|c|c|}
\hline Indicators & Southern semi-arid & Central semi-arid & Northern semi-arid \\
\hline Quality residential house & 0.869 & 0.224 & -1.093 \\
\hline The size of farmland & 1.017 & -0.035 & -0.982 \\
\hline Dependency ratio & 0.673 & 0.476 & -1.149 \\
\hline Access to drinking water & 0.266 & -1.106 & 0.840 \\
\hline Human capital/literacy rate & -1.123 & 0.794 & 0.329 \\
\hline Social capital & -1.015 & 0.031 & 0.984 \\
\hline Nonfarm activity & 0.409 & -1.140 & 0.731 \\
\hline Access to information & 0.817 & 0.298 & -1.115 \\
\hline User of microfinance & 1.144 & -0.710 & -0.433 \\
\hline Rainfall Variability & 1.153 & -0.632 & -0.521 \\
\hline Change in temperature & -1.120 & 0.316 & 0.803 \\
\hline Temperature variability & -0.614 & 1.154 & -0.540 \\
\hline Access to the main road & 1.006 & -0.994 & -0.013 \\
\hline Change in rainfall & 1.126 & -0.784 & -0.342 \\
\hline Trees on farmland & 0.727 & 0.413 & -1.140 \\
\hline Access to health post & 0.523 & 1.153 & 0.630 \\
\hline Access to primary school & -0.203 & -0.883 & 1.086 \\
\hline Access to veterinary service & -1.094 & 0.866 & 0.240 \\
\hline Access to agricultural technology & -0.764 & -0.368 & 1.132 \\
\hline Access to health center/hospital & -0.140 & -0.922 & 1.063 \\
\hline Access to market & -0.288 & -0.825 & 1.112 \\
\hline Access to secondary school & -0.172 & -0.903 & 1.075 \\
\hline Cereal yield & -1.005 & 0.995 & 0.009 \\
\hline Livestock ownership & 1.087 & -0.205 & -0.881 \\
\hline Beneficiary of irrigation/water harvesting & 0.542 & -1.154 & 0.612 \\
\hline
\end{tabular}

*Standard deviation and centering normalization technique was used to normalize the dataset. 